\title{
Ocena skuteczności wybielania zębów żywych oraz wpływ substancji czynnej na tkanki zęba - przegląd piśmiennictwa
}

\author{
Assessment of vital teeth whitening efficacy and the impact of active agents \\ on tooth tissues - literature review
}

Klinika Stomatologii Zachowawczej i Endodoncji, Uniwersytet Medyczny im. Karola Marcinkowskiego w Poznaniu

DOI: http://dx.doi.org/10.20883/df.2020.6

\begin{abstract}
STRESZCZENIE
Nadtlenek wodoru, dostarczany w postaci niezmienionej lub jako produkt rozkładu nadtlenku karbamidu, znajduje zastosowanie podczas zabiegów wybielania zębów żywych. Wykazano, że substancja czynna zawarta w preparatach do rozjaśniania zębów zmniejsza mikrotwardość szkliwa oraz może powodować stany zapalne miazgi. W celu minimalizacji negatywnego wpływu nadtlenku wodoru stosuje się związki remineralizujące. Kompleks fosfopeptyd kazeiny-amorficzny fosforan wapnia (CPP-ACP), nanohydroksyapatatyt (nHA) oraz wapń powodują ponowne zwiększenie mikrotwardości szkliwa. Ponadto CPP-ACP zastosowany w trakcie wybielania zębów zmniejsza penetrację nadtlenku wodoru do jamy zęba. W praktyce stomatologicznej wykorzystuje się dwie metody wybielania zębów żywych: profesjonalną, polegającą na aplikacji preparatu bezpośrednio na zęby w gabinecie dentystycznym oraz nakładkową, w której lekarz posługuje się indywidualnie przygotowanymi szynami. Wykazano, że obie metody wybielania zębów żywych cechują się równą skutecznością, a efekt wybielania pozostaje stabilny. Największą zmianę koloru uzyskuje się przy połączeniu obu wyżej wymienionych metod.
\end{abstract}

Słowa klucze: wybielanie zębów, nadtlenek wodoru, fosforan wapnia, szkliwo zębów, kolor.

\section{ABSTRACT}

Hydrogen peroxide is used during vital teeth whitening procedures and is supplied unaltered or as a decomposition product of carbamide peroxide. It has been shown that the active substance presented in bleaching products reduces microhardness of enamel and may cause pulp inflammation. In order to minimize the adverse effect of hydrogen peroxide, remineralizing compounds are used in the treatment. Casein phosphopepetides and amorphous calcium phosphate complex (CPP-ACP), nanohydroxyapatite ( $\mathrm{nHA})$, as well as calcium increase the microhardness of enamel. Moreover, CPP-ACP applied during a whitening procedure reduces the penetration of hydrogen peroxide into the tooth structure. In dental protocol, two techniques of vital teeth bleaching are used: a professional method involving the application of the special product directly to the teeth, and tray-based teeth whitening, in which individually prepared dental splints are provided by dentist. It has been demonstrated that both techniques of vital teeth whitening are equally effective, and that the post-effect remains safe and stable. However, the highest colour diversity is achieved by combining the two above-mentioned methods.

Keywords: teeth bleaching, hydrogen peroxide, calcium phosphate, dental enamel, colour.

\section{Wstęp}

Wybielanie zębów żywych zyskuje w ostatnich latach na popularności, co związane jest, między innymi, ze zmieniającym się kanonem piękna, rozwojem stomatologii estetycznej oraz z coraz częstszym zwracaniem uwagi na wygląd zewnętrzny. Troska o urodę jest czynnikiem predykcyjnym do przeprowadzania kosmetycznych zabiegów stomatologicznych [1], natomiast w skrajnych przypadkach prowadzić może do tak zwanej bleachoreksji, czyli obsesyjnego dąże- nia do posiadania coraz bardziej białych zębów [2]. Przeprowadzenie zabiegów wybielania zębów oraz długotrwałe utrzymywanie się efektów może wpłynąć pozytywnie na dobrostan psychospołeczny, postrzeganie estetyki własnych zębów [3-5], a także na subiektywną ocenę zdrowia jamy ustnej $[5,6]$. Wykazano, że na chęć zmiany koloru zębów wpływać mogą takie czynniki, jak regularność wizyt u stomatologa, palenie papierosów czy samoocena własnego uśmiechu [7]. 


\section{Czynniki wpływające na odbiór koloru zębów}

Postrzeganie koloru stanowi subiektywną ocenę, na którą wpływa, między innymi, anatomia i fizjologia narządu wzroku oraz parametry fizyczne, jak kąt padania promieni świetlnych. Odbieranie barwy zęba zależne jest od budowy szkliwa i zębiny [8, 9]. Prawidłowo zmineralizowane szkliwo, ze względu na swoją przezierność, powoduje przeświecanie żółtej zębiny. Takie zęby są bardziej odporne na próchnicę [10], aczkolwiek jednocześnie wydają się być mniej estetyczne. Ze względu na stosunek wapnia do fosforu w szkliwie oraz dysproporcje w grubości i gęstości tkanek twardych wchodzących w skład korony anatomicznej, kolor zębów w uzębieniu stałym i mlecznym różni się. Rozbieżności w kolorze dostrzegalne są również pomiędzy poszczególnymi osobami, czy grupami zębowymi. Przyjmuje się, iż najciemniejszymi zębami w łuku są kły oraz, że zęby przednie w żuchwie są jaśniejsze niż zęby przednie w szczęce. Kolor zęba różni się w zależności od położenia w stosunku do brzegu dziąsła. Brzeg sieczny jest najbardziej przezierny, natomiast okolica przyszyjkowa jest najciemniejszą częścią korony anatomicznej [10].

\section{Nadtlenek wodoru jako substancja czynna}

Środki wybielające zęby można podzielić na dwie grupy: środki stosowane $w$ domu bez nadzoru lekarza oraz przeznaczone do profesjonalnego zastosowania w gabinecie stomatologicznym. Rozwiązaniem pośrednim jest wykorzystywanie $w$ domu preparatów do wybielania zębów zgodnie z zaleceniami lekarza dentysty. Substancję czynną stosowaną w metodach profesjonalnych i półprofesjonalnych stanowi nadtlenek wodoru, który może być stosowany $w$ formie niezmienionej lub pochodzić z rozkładu nadtlenku karbamidu (mocznika) [11]. Wg dyrektyw obowiązujących od dnia 31 października 2012 roku na terenie państw członkowskich Unii Europejskiej maksymalne dopuszczane stężenie nadtlenku wodoru w preparatach stosowanych bez nadzoru lekarza dentysty wynosi $0,1 \%$. Do użytku profesjonalnego lub pod kontrolą lekarza akceptuje się wyroby zawierające do $6 \%$ nadtlenku wodoru obecnego lub uwolnionego. Wraz z pojawieniem się nowych przepisów preparaty zawierające substancje czynne o wyższych stężeniach zostały wycofane z rynku europejskiego [12].

\section{Rodzaje wybielania zębów - efekt i jego stabilność}

Lekarz dentysta podczas kwalifikacji pacjenta do zabiegu wybielania zębów podejmuje decyzję do- tyczącą sposobu przeprowadzenia procedury. $\mathrm{Na}$ Wydziale Stomatologicznym Uniwersytetu Otago w Dunedin w Nowej Zelandii porównywano zmianę koloru zęba i satysfakcję badanych w zależności od zastosowanej metody wybielania zębów. Pacjentów przygotowano do zabiegu poprzez całkowite usunięcie złogów nazębnych i podzielono na trzy grupy. Każdy uczestnik badania miał zalecone stosowanie pasty do zębów niezawierającej żadnego związku wybielającego (Colgate Sensitive PRO-Relief, Colgate-Palmolive). Pierwsza grupa otrzymała indywidualną szynę do wybielania, 10\% żel nadtlenku karbamidu (Polanight, SDI, Australia) oraz zalecenia stosowania preparatu przez 8 godzin w nocy, przez 14 dni. Pacjenci, którym zalecono wybielanie metodą profesjonalną mieli trzykrotnie nakładany na zęby żel zawierający 37,5\% nadtlenku wodoru (Pola in-office+, SDI, Australia). $\mathrm{U}$ trzeciej grupy pacjentów połączono wybielanie nakładkowe z gabinetowym. Wyniki doświadczenia wskazały, że wszystkie protokoły wybielające skutkują efektem rozjaśnienia równym lub większym niż cztery tony koloru w ciągu 15 dni, a jego poprawa utrzymuje się po upływie 6 miesięcy. Połączenie obu metod wybielania zębów powoduje bardziej wyraźną poprawą koloru. Niezależnie od wybranej procedury zadowolenie pacjentów z uśmiechu i bieli zębów poprawia się i skutkuje wyższą oceną zdrowia jamy ustnej [6].

Porównania różnych metod wybielania zębów dokonano również na Uniwersytecie Medycznym w Wiedniu. Badania przeprowadzone zostały na zębach bydlęcych podzielonych na cztery grupy. Pierwsza grupa stanowiła grupę kontrolną. Testowano preparaty stosowane do wybielania nakładkowego i zawierające $\leq 6 \%$ nadtlenku wodoru (Opalescence PF 10\%, Philips ZOOM NiteWhite $16 \%$, Philips ZOOM DayWhite 6\%), środki przeznaczone do użycia w gabinecie o stężeniu procentowym substancji czynnej $\leq 6 \%$ (Philips ZOOM 6\%, Magic White $0 \%$, Smartbleach $6 \%$ ) oraz produkty do wybielania profesjonalnego o stężeniu powyżej $6 \%$ nadtlenku wodoru (Philips ZOOM 25\%, OpalescenceBoost 40\%, Philips Dash 30\%). Statystycznie istotne różnice wykryto tylko między preparatami przeznaczonymi do stosowania w gabinecie o stężeniu $\leq 6 \% \mathrm{HP}$ - Philips ZOOM 6\% wykazało lepsze efekty niż Magic White 0\% i Smartbleach $6 \%$. Kolejno porównano między sobą najskuteczniejsze produkty z każdej z grup, nie udokumentowano rozbieżności w uzyskiwanych efektach [13].

Podjęto próbę porównania oceny skuteczności wybielania metodą gabinetową oraz skojarzoną. W tym celu przeprowadzono badania in vitro 
na zębach ludzkich umieszczonych w modelach gipsowych kształtu podkowy. Wybielanie przeprowadzone zostało odpowiednio 37,5\% nadtlenkiem wodoru (Pola office+, SDI, Australia) oraz wymienionym preparatem $\mathrm{w}$ połączeniu $\mathrm{z}$ metodą nakładkową - 16\% nadtlenek karbamidu (Pola Night, SDI, Australia). Ocena koloru została wykonana za pomocą spektrofotometru (VitaEasyshade, Vita) przed przystąpieniem do zabiegów oraz na tydzień po zakończeniu leczenia. Miało to na celu umożliwienie ostatecznej stabilizacji koloru. Wykazano skuteczność obu technik wybielania, z lepszymi efektami w przypadku zastosowania metody skojarzonej [14].

Retrospektywnej oceny efektów wybielania zębów żywych dokonano na Wydziale Stomatologii Uniwersytetu w Walencji. Pacjenci stosowali preparat zawierający 16\% nadtlenek karbamidu (Polanight, SDI, Australia) nałożony na indywidualnie przygotowane nakładki. Wybielanie trwało 4 tygodnie, a preparat stosowany był przez 90 minut dziennie. Parametry koloru mierzone były za pomocą spektrofotometru przed zabiegiem, 1 tydzień po zakończeniu stosowania nadtlenku karbamidu oraz co 6 miesięcy aż do ukończenia 42-miesięcznego okresu obserwacji. Wykazano, iż zastosowanie opisanej metody powoduje znaczną zmianę koloru, a efekt leczenia pozostaje stabilny nawet po 42 miesiącach [15].

\section{Wpływ środków wybielających na szkliwo i miazgę}

Od lat dyskutuje się o wpływie wybielania zębów na szkliwo oraz dąży się do określenia optymalnego stężenia i pH środków wybielających. Badacze z Kliniki Stomatologii Odtwórczej Instytutu Nauki i Technologii w Sao Jose w Brazylii podjęli próbę oceny w warunkach in vitro oddziaływania $35 \%$ nadtlenku wodoru o różnych wartościach $\mathrm{pH}$ na skuteczność wybielania i mikrotwardość szkliwa. Doświadczenie przeprowadzone zostało na siekaczach bydlęcych, które losowo podzielono na dwa zbiory - jedna z grup przed zastosowaniem nadtlenku wodoru poddana została procesowi barwienia. Wybielanie trwało $30 \mathrm{~min}$ i przeprowadzone zostało żelami o trzech różnych pH - 5,0, 7,0 oraz 8,4. Wykazano, iż szkliwo poddane procesowi wybielania 35\% nadtlenkiem wodoru ulega demineralizacji na powierzchni, a i jego mikrotwardość zmniejsza się niezależnie od pH zastosowanego preparatu. Po wybielaniu bardziej dostrzegalna była zmiana koloru zębów przebarwionych, a pH nadtlenku wodoru nie miało wpływu na efekt wybielania [16].
Spadek mikrotwardości szkliwa zębów poddanych procesowi wybielania potwierdziły badania przeprowadzone w ramach współpracy Klinik Stomatologii Zachowawczej i Endodoncji Szkół Wyższych w Nellore i Chennai [17] oraz na Uniwersytecie Unicamp w Campinas [18] w Indiach. Analizowano wpływ dostępnej na rynku pasty z amorficznym fosforanem wapnia (CPP-ACP) i nano-hydroksyapatytu (nHA) uzyskanego ze skorupki jaja kurzego na szkliwo zębów ludzkich poddane procesowi wybielania. Substancją czynną powodującą rozjaśnienie zębów był 30\% nadtlenek wodoru. W przypadku niezastosowania preparatów remineralizujących wykazano znaczny spadek mikrotwardości szkliwa po procesie wybielania. Zastosowanie $\mathrm{nHA}$ lub CPP-ACP z podobną skutecznością powodowało ponowny wzrost mikrotwardości szkliwa [17]. Natomiast w Brazylii oceniano wpływ środków remineralizujących, jak wapń (Ca) i fluor (F) na skutki wybielania. W badaniu posłużono się preparatami zawierającymi 35\% nadtlenek wodoru (Whiteness HP, FGM), 35\% nadtlenek wodoru + Ca (Whiteness HP Blue, FGM), 40\% nadtlenek wodoru + F (OpalescenceBoost, Ultradent). Spadku mikrotwardości szkliwa w porównaniu do grupy kontrolnej nie wykazano tylko w sytuacji zastosowania środka wybielającego wzbogaconego jonami wapnia. Stwierdzono, że wapń i fluor nie zakłócały procesu rozjaśniania zębów, a średnie zmiany barwy były wyższe niż 4,2 jednostki [18].

Obecność zmian w morfologii szkliwa po zastosowaniu $37,5 \%$ nadtlenku wodoru oraz $35 \%$ nadtlenku karbamidu wykazano także na Wydziale Stomatologii Uniwersytetu w Walencji. Zastosowane preparaty nie spowodowały zmian w zębinie. Aplikacja kompleksu fosfopeptydu kazeiny i amorficznego fosforanu wapnia z fluorem przez pięć minut po wybielaniu przyczyniła się do wzrostu zawartości wapnia w szkliwie [19].

Kolejną tkanką, na którą może oddziaływać środek wybielający, jest miazga. W Klinice Stomatologii Dziecięcej na Uniwersytecie Medycznym w Teheranie podjęto próbę oceny in vitro przenikania nadtlenku wodoru do jamy zęba podczas procesu wybielania zębów z użyciem lasera diodowego. W tym celu posłużono się siekaczami szczęki usuniętymi i podzielonymi na pięć grup. Grupa pierwsza została poddana działaniu tylko środka wybielającego (OpalescenceBoost, Ultradent), na zęby z grup od dwa do cztery naniesiony został żel wybielający (Laser White 20, Biolase), plus zastosowano laser o różnej długości fali (odpowiednio: $980 \mathrm{~nm}, 810 \mathrm{~nm}, 940 \mathrm{~nm}$ ); ostatnia była grupa kontrolna. Wykazano, że nadtlenek wodoru przedosta- 
je się do jamy zęba podczas wybielania, zarówno gdy stosowany był sam preparat, jak również w sytuacji gdy wspomagano się laserem. Długość fali ma wpływ na stopień penetracji środka do jamy zęba - najwięcej nadtlenku wodoru przedostało się do komory miazgi podczas zastosowania lasera o długości fali $980 \mathrm{~nm}$, a najmniej gdy użyto lasera o długości fali $810 \mathrm{~nm}$ [20].

W celu ustalenia optymalnego protokołu wybielania zębów przeprowadzono badania in vivo na szczurach oraz in vitro na siekaczach bydlęcych oceniające wpływ na komórki miazgi 35\% nadtlenku wodoru w połączeniu z Mi Paste Plus (CPP-ACP: fosfopeptyd kazeiny - amorficzny fosforan wapnia). Doświadczenia wykonane zostały w ramach współpracy Kliniki Endodoncji Uniwersytetu Stanowego w Sao Paulo oraz Kliniki Stomatologii Zachowawczej Federalnego Uniwersytetu Minas Gerais. Wykazano, że 35\% nadtlenek wodoru penetruje do komory zęba oraz powoduje miejscowy stan zapalny $\mathrm{w}$ miazdze. $\mathrm{W}$ badaniu porównano kilka protokołów wybielania w połączeniu z CPP-ACP. Mi Paste Plus stosowano przed, po, przed i po lub $w$ trakcie wybielania z użyciem $35 \%$ nadtlenku wodoru. Równoczesne zastosowanie żelu wybielającego i remineralizatora na bazie CPP-ACP spowodowało niższą penetrację $\mathrm{H}_{2} \mathrm{O}_{2}$ do komory zęba oraz mniejsze uszkodzenie tkanki miazgi. Nie odnotowano statystycznie istotnych różnic między efektami wybielania w przypadku aplikacji nadtlenku wodoru i Mi Paste Plus w porównaniu do grupy wybielanej tylko nadtlenkiem wodoru [21].

\section{Podsumowanie}

Wybielanie zębów żywych jest procedurą stomatologiczną przeprowadzaną ze względu na subiektywne potrzeby pacjenta, a celem zabiegu jest poprawa estetyki uśmiechu. Przed podjęciem decyzji o kwalifikacji do leczenia, lekarz dentysta powinien dokonać analizy możliwych skutków ubocznych, jak również negatywnego wpływu substancji czynnej na szkliwo oraz miazgę. $Z$ tego względu, specjalistyczny wywiad medyczny, rozmowa poprzedzająca zabieg oraz poznanie oczekiwań pacjenta są szczególnie istotne. Niezbędna jest również dokumentacja fotograficzna, jak i ocena wyjściowego koloru zębów za pomocą kolornika. Umożliwi to ocenę efektów wybielania oraz stanowić będzie narzędzie w rozmowie z pacjentem. W sytuacji zgłoszenia się do gabinetu stomatologicznego pacjenta małoletniego lub kobiety ciężarnej, z uwagi na potencjalnie toksyczny wpływ nadtlenku wodoru na tkanki żywe, lekarz dentysta powinien unikać zabiegu rozjaśniania zębów oraz poinformować o powodach takiej decyzji. Przeprowadzenie zabiegu wybielania, każdorazowo, wymaga podjęcia optymalnego protokołu postępowania, co minimalizuje negatywne oddziaływania nadtlenku wodoru na tkanki żywe zęba. Obecnie na rynku stomatologicznym oraz kosmetycznym dostępnych jest wiele preparatów mających na celu poprawę estetyki uśmiechu. Produkty różnią się od siebie, między innymi: składem, stężeniem substancji czynnej czy pH. Innowacyjnym rozwiązaniem wydaje się być łączenie środków wybielających ze związkami powodującymi remineralizację szkliwa. Szczególną rolę może odgrywać CPP-ACP, który zastosowany podczas wybielania pozytywnie wpływa na mikrotwardość szkliwa [17], ale także zmniejsza penetrację nadtlenku wodoru do jamy zęba [21]. Zastosowanie tych związków może zapobiec odczuwanej przez pacjenta nadwrażliwości pozabiegowej, jak i zmniejszyć ryzyko skutków ubocznych. Ze względu na możliwe działania niepożądane warto jest przestrzegać pacjentów przed stosowaniem preparatów wybielających samodzielnie w domu, bez konsultacji z lekarzem.

Podczas kwalifikacji pacjenta do zabiegu istotnym aspektem jest wybór metody wybielania zębów. Zarówno wybielanie profesjonalne w gabinecie stomatologicznym, jak i domowy zabieg metodą nakładkową z użyciem indywidualnej szyny przynosi oczekiwany oraz zadowalający efekt $[6,13]$. Jest to ważne, szczególnie w sytuacji gdy u pacjenta występują przeciwwskazania do zastosowania obu metod wybielania, na przykład z uwagi na dysfunkcję stawu skroniowo-żuchwowego. W przypadku bardziej wymagających pacjentów warto rozważyć zastosowanie metody skojarzonej, która umożliwia uzyskanie lepszych efektów estetycznych [6, 14]. Istotne jest, aby każdego pacjenta traktować indywidualnie oraz dobrać odpowiednią metodę rozjaśnienia zębów, biorąc pod uwagę najnowsze zalecenia, substancję czynną produktów oraz wpływ na zęby w codziennym użytkowaniu.

\section{Oświadczenia}

Oświadczenie dotyczące konfliktu interesów Autorzy deklarują brak konfliktu interesów w autorstwie oraz publikacji pracy.

Źródła finansowania

Autorzy deklarują brak źródeł finansowania.

\section{Piśmiennictwo}

[1] De Jongh A, Oosterink FM, van Rood YR, Aartman $\mathrm{IH}$. Preoccupation with one's appearance: a motivating factor for cosmetic dental treatment? Br Dent J. 2008;204(12):691-5. 
[2] Lee DK, Kastl C, Chan DC. Bleachorexia-an addictive behavior to tooth bleaching: a case report. Clin Case Rep. 2018;6(5):910-4.

[3] Fernández E, Bersezio C, Bottner J, Avalos F, Godoy I, Inda D, Vildósola P, Saad J, Oliveira OB, Martin J. Longevity, Esthetic Perception, and Psychosocial Impact of Teeth Bleaching by Low (6\%) Hydrogen Peroxide Concentration for In-office Treatment: A Randomized Clinical Trial. Oper Dent. 2017;42(1):41-52.

[4] Kothari S, Gray AR, Lyons K, Tan XW, Brunton PA. Vital bleaching and oral-health-related quality of life in adults: A systematic review and meta-analysis. J Dent. 2019;84:22-9.

[5] Meireles SS, Goettems ML, Dantas RV, Bona ÁD, Santos IS, Demarco FF. Changes in oral health related quality of life after dental bleaching in a double-blind randomized clinical trial. J Dent. 2014;42(2):114-21.

[6] Kothari S, Jum'ah AA, Gray AR, M Lyons K, Yap M, Brunton $P A$. A randomized clinical trial investigating three vital tooth bleaching protocols and associated efficacy, effectiveness and participants' satisfaction. J Dent. 2020;95:103322.

[7] Silva FB, Chisini LA, Demarco FF, Horta BL, Correa $M B$. Desire for tooth bleaching and treatment performed in Brazilian adults: findings from a birth cohort. Braz Oral Res. 2018;32:e12.

[8] Oguro R, Nakajima M, Seki N, Sadr A, Tagami J, Sumi $Y$. The role of enamel thickness and refractive index on human tooth colour. J Dent. 2016;51:36-44.

[9] Battersby PD, Battersby SJ. Measurements and modelling of the influence of dentine colour and enamel on tooth colour. J Dent. 2015;43(3):373-81.

[10] Arabska-Przedpełska B, Buczkowska-Radlińska J, Dura W, Grzebieluch W, Jańczuk Z, Kaczmarek U. Lipski M, Lisiecka K, Piątowska D, Woźniak K. Stomatologia zachowawcza z endodoncją. Zarys kliniczny. Wybielanie przebarwionych zębów. Wydawnictwo Lekarskie PZWL. Warszawa; s. 503-511.

[11] Eachempati P, Kumbargere Nagraj S, Kiran Kumar Krishanappa S, Gupta P, Yaylali IE. Home-based chemically-induced whitening (bleaching) of teeth in adults. Cochrane Database Syst Rev [Internet]. 18 grudzień 2018 [cytowane 22 kwiecień 2020]; 2018(12). Dostępne na: https://www.ncbi.nlm.nih. gov/pmc/articles/PMC6517292/

[12] Dyrektywa Rady 2011/84/UE z dnia 20 września 2011 r. zmieniająca dyrektywę 76/768/EWG dotyczącą produktów kosmetycznych w celu dostosowania jej załącznika III do postępu technicznego. Tekst mający znaczenie dla EOG. Dziennik Urzędowy Unii Europejskiej L286/36

[13] Lilaj B, Dauti R, Agis H, Schmid-Schwap M, Franz A, Kanz F, Moritz A, Schedle A, Cvikl B. Comparison of Bleaching Products With Up to $6 \%$ and With More Than 6\% Hydrogen Peroxide: Whitening Efficacy Using $\mathrm{BI}$ and WID and Side Effects - An in vitro Study. Front Physiol. 2019;10:919.
[14] Faus-Matoses V, Palau-Martínez I, Amengual-Lorenzo J, Faus-Matoses I, Faus-Llácer VJ. Bleaching in vital teeth: Combined treatment vs in-office treatment. J Clin Exp Dent. 2019;11(8):e754-8.

[15] Llena C, Villanueva A, Mejias E, Forner L. Bleaching efficacy of at home $16 \%$ carbamide peroxide. A long-term clinical follow-up study. J Esthet Restor Dent. 2020;32(1):12-8.

[16] Jurema AL, de Souza MY, Torres CR, Borges AB, Caneppele TM. Effect of $\mathrm{pH}$ on whitening efficacy of $35 \%$ hydrogen peroxide and enamel microhardness. J Esthet Restor Dent. 2018;30(2):E39-44.

[17] Kunam D, Sampath V, Manimaran S, Sekar M. Effect of Indigenously Developed Nano-Hydroxyapatite Crystals from Chicken Egg Shell on the Surface Hardness of Bleached Human Enamel: An In Vitro Study. Contemp Clin Dent. 2019;10(3):489-93.

[18] Vieira I, Vieira-Junior WF, Pauli MC, Theobaldo JD, Aguiar FH, Lima DA, Leonardi GR. Effect of in-office bleaching gels with calcium or fluoride on color, roughness, and enamel microhardness. J Clin Exp Dent. 2020;12(2):e116-22.

[19] Llena C, Esteve I, Rodríguez-Lozano FJ, Forner L. The application of casein phosphopeptide and amorphous calcium phosphate with fluoride (CPP-ACPF) for restoring mineral loss after dental bleaching with hydrogen or carbamide peroxide: An in vitro study. Ann Anat. 2019;225:48-53.

[20] Abbasi M, Pordel E, Chiniforush N, Firuzjaee SG, Omrani LR. Hydrogen peroxide penetration into the pulp chamber during conventional in-office bleaching and diode laser-assisted bleaching with three different wavelengths. Laser Ther. 2019;28(4):28590.

[21] Barbosa JG, Benetti F, de Oliveira Gallinari M, Carminatti $M$, da Silva AB, Lopes IN, Briso AL, Cintra LT. Bleaching gel mixed with $\mathrm{MI}$ Paste Plus reduces penetration of $\mathrm{H}_{2} \mathrm{O}_{2}$ and damage to pulp tissue and maintains bleaching effectiveness. Clin Oral Investig. 2020;24(3):1299-309.

Zaakceptowano do edycji: 2020-06-01 Zaakceptowano do publikacji: 2020-06-15

Adres do korespondencji:

Klinika Stomatologii Zachowawczej i Endodoncji Uniwersytet Medyczny im. Karola Marcinkowskiego w Poznaniu

ul. Bukowska 70, 60-812 Poznań

tel.: 618547026, 618547027

e-mail: stomzach@ump.edu.pl 